\title{
Synthetic Cathinones and Cannabinoids Are New Psychoactive Substances (Review)
}

\author{
DOI: $10.17691 / \mathrm{stm} 2017.9 .1 .23$
}

Received May 25, 2015

A.V. Larchenko, PhD Student, Department of Emergency Medical Care;

M.A. Suvorov, MD, PhD, Associate Professor, Department of Emergency Medical Care;

V.I. Andryukhin, MD, DSc, Professor, Department of Emergency Medical Care;

Ya.V. Kaurov, MD, DSc, Associate Professor, Department of Emergency Medical Care;

A.V. Suvorov, MD, DSc, Professor, Department of Emergency Medical Care

Nizhny Novgorod State Medical Academy, 10/1 Minin and Pozharsky Square, Nizhny Novgorod, 603005, Russian Federation

New psychoactive substances, or designer drugs, are currently a large group of substances, primarily of synthetic origin, which are designed and come on a shadow market in circumvention of the current law. The popularity of these substances among young people is due to the off-the-shelf availability, low cost, and expected safety compared to traditional drugs. As practice shows, a resulting intoxication is life-threatening.

Currently, the ordered data on these substances classes, as well as clinical manifestations of poisoning related to their consumption is practically non-existent due to certain difficulties in their diagnosis. The review considers the main groups of new psychoactive substances (synthetic cathinones and cannabinoids, derivatives of piperazine, aminoindans) circulating in a shadow market. We have distinguished the basic mechanisms of their effect on human body and described the main manifestations of their consumption.

When writing the review we used the data of specialized poison control medical centers, as well as the information obtained from users.

Key words: new psychoactive substances; synthetic cathinones; bath salts; mephedrone; synthetic cannabinoids; spice.

New psychoactive substances (NPS) are substances synthesized for scientific or medical studies, as well as the derivatives of these substances or previously detected drugs, which exhibit a marked effect, primarily, on the nervous system, up to complete consciousness change. They can be classified based on clinical effects (sedatives, stimulators and psycholytic drugs) or their chemical structure [1]. These substances are sold illegally [2].

In recent years the number of new NPS in Western countries and in Russia has been increasing. In 2010 the early warning system (European Monitoring Center on new drugs and drug abuse) distinguished the emergence of 41 new substances, in 2011 - 49, and in 2012 - 73. The most spread substances are synthetic cannabinoids (39.3\%), synthetic cathinones (16.6\%) and phenylethylamines (14.1\%); piperazine and tryptamines being less common [3].

A chemical structure of a great number of sell substances is still unknown. Due to the fact that only some substances, not their classes can be forbidden and fall within the scope of the law, manufacturers offer new derivatives to consumers. The situation could be mended as a result of amendments to laws enabling to lay an embargo on substance classes, but in this case many medical pharmaceuticals can appear under a ban.
In the meantime NPS consumers network discussing the emergence of new substances, their dosages, effect and side effects. NPS can be ordered through online shopping with a subsequent mail delivery. They are easily available and popular with consumers due to their supposed legality, a low price, and perceived low risk for health [4].

NPS are not detected by standard immunoassays used for a drug screening examination. Synthetic cannabinoids are not detected by a standard THC test, as well as synthetic cathinones are not detected by amphetamine ELISA test. However, a few NPS are determined by standard methamphetamine tests. Piperazine ring comprising some substances brings confounded results in a standard amphetamine test [5]. For NPS detection, other tests are usually used, more complex, such as gas chromatography mass spectrometry (GC-MS) and liquid chromatography mass spectrometry (LC-MS/MS). Thus, the necessary analysis can be carried out only in a toxicological laboratory or a medico-legal institution [5-7].

Many NPS are not clinically studied, and no information is available about them. Controlled trials are sometimes difficult to carry out due to methodological difficulties. Most available data are obtained through retro- or prospective studies of clinical records of patients undergoing medical treatment for NPS, as well as past

For contacts: Artyom V. Larchenko, e-mail: worshif@mail.ru 
history data of drug-addicts. Therefore, the obtained information has low scientific value. The description of symptoms arising from taking a certain substance is impeded, since a substance is scarcely ever detected or the intoxication is due to the consumption of several substances.

To analyze the current situation, assess pharmacological and clinical effects of the most common NPS classes, we have chosen and studied the publications with the data on pharmacology, epidemiology, clinical manifestations of NPS effects, as well as the reports of monitoring centers of European and American countries.

\section{New psychoactive substances usage in Europe and USA}

Now it is hard to say when these substances have gained popularity and become wide spread, but they were first mentioned in USA in 2006, in Europe they have been first reported about since 2008, in Russia since 2009 [8].

In Germany drug trafficking is under government control, and governed by Medicines Act (Arzneimittelgesetz, AMG) and Drug Act (Betäubungsmittelgesetz, BtMG). To dodge the law, NPS are presented as chemical substances for researches, herb repertory or aromatic bath salts, and marked "for external application only". It will take a long time to detect and report about a new substance, which includes its characteristics, control measures at the European level, and, finally, the implementation of elaborated instructions by common European national legislative authorities. Thus, a great number of NPS fall outside the scope of BtMG law.

Before 2009 UK Poisons Information Service did not record telephone calls related to synthetic cathinones. However, over the period from 2009 to 2010 the number of inquiries for synthetic cathinones and their derivatives equaled to those for cocaine and MDMA (3,4-methylenedioxymethamphetamine) [9]. Web-based Google application, which monitors the search criteria and volume, demonstrates no inquiries for mephedrone before 2008. The situation drastically changed in 2009, when in Great Britain the inquiries for mephedrone set records and reached a peak. Most synthetic cathinones became popular due to their legal status.

A great deal of evidence on using NPS has been collected in MoSyD study (Monitoring System for Drug Trends, Frankfurt on the Main, Germany) [10]. In 2012 the abundance of NPS usage was found in $7 \%$ of population aged $15-18$. Moreover, $16 \%$ respondents declared that they knew others who used NPS. More information has emerged about NPS usage in clubs and among young people at risk. Hermanns-Clausen et al. [11] analyzed the data on 50 patients who were admitted to the emergency department, and were reported to Freiburg Toxicological Centre due to the suspected intoxication by synthetic cathinones from September 2008 to April 2011. In addition, there are reports in Germany including the descriptions of cases with those driving under the effect of synthetic cathinones [12], and case histories of patients with abstinence symptoms and drug abuse after taking the spice under the trademark "spice gold" [13].

As in the situation with many "classical" drugs, it is very difficult to evaluate the prevalence of synthetic cathinones. Most of the information was obtained from reports run during the treatment of drug abusers. Online enquiry of night club visitors in Great Britain showed that $41 \%$ respondents used mephedrone and $10 \%-$ methylone. One third used mephedrone last month, and $14 \%$ respondents reported about its weekly consumption [14]. Another enquiry, in which UK secondary school students and college students took part, demonstrates $20 \%$ of them to have used mephedrone at least once, and $4 \%$ students reported about daily consumption, all respondents being under 21 [15].

The authors of the Finnish study [16] analyzed the blood of drivers suspected in driving while intoxicated, and found that 286 of 3,000 tests contained MDPV (methylenedioxypyrovalerone) (8.6\%). 208 of these drivers were tested using such tests as walking on a flat surface, a speech test, and then detained and referred to medical testing. The blood count in most users appeared to have several substances including benzodiazepines, amphetamines, tetrahydrocannabinol and ethanol.

In USA, the data on NPS prevalence and usage are extremely limited. American Association of Poison Control Centers reported about 303 phone calls related to bath salts in 2010, and 2,371 phone calls were recorded in May 2011.

A detail study of NPS prevalence among adolescents enables to conclude that the number of users is greater than those mentioned in statistical reports. The reasons can be the following: the lack or unavailability of information; imperfection of tests for drug detection; rare confirmation by laboratory testing in patients with clinical presentation of unclear etiology and/or uncommon intoxication compared to consumption.

Mephedrone users report about two main ways of purchasing: internet and local dealers. Purchase in retail dealers has become more preferable due to the prohibitions in legislation of many countries, e.g. Great Britain $[14,17]$. Currently, the cost of $1 \mathrm{~g}$ of mephedrone in Great Britain is about $16 £(25 \$)$, it is $10 £$ more than that before the prohibition [17]. In USA $1 \mathrm{~g}$ of the substance costs $20-35 \$$ [18].

Synthetic cathinones can be bought in three main forms: powders, pills, capsules. In 95\% cases, when they were withdrawn by Scotland Yard officers, synthetic cathinones were in a form of powder.

\section{Synthetic cathinones}

Synthetic cathinones are the derivatives of bkamphetamine ( $\beta$-keto- $\alpha$-methyl-phenylalkilamin), which 
is chemically similar to methamphetamine "cristal meth" and 3,4-methylenedioxymethamphetamine ecstasy [19] (Figure 1).

Cathinone is isolated from natural raw material: Catha edulis growing in Yemen, local citizens chew it to experience a psycho-stimulating effect [20]. Cathinone extracted from the leaves of this plant acts unless the leaves are flaccid, that is why it can be chewed for several days only.

Cathinone like amphetamine causes sympathomimetic effects including tachycardia and arterial hypertension, and has a psychotropic effect causing euphoria and enhancing anxiety. Regular chewing of the leaves is related to a high risk of myocardial infarction, dilated cardiomyopathy and duodenal ulcer [21].

Cathinone derivatives were used as antidepressants in the Soviet Union in 1930s [22, 23]. Methamphetamine was given to German soldiers during World War II under the trademark Pervitin to struggle with fatigue. Such pharmaceutical as pyrovalerone was studied in France and USA; in 1970 it was used as a stimulator in patients with chronic fatigue. The studies carried out showed its stimulating effect on CNS and revealed motor hyperactivity in volunteers [24].

Synthetic cathinones, especially mephedrone, are currently sold as aromatic bath salts. They can be in the form of crystals of white, beige or brown color [25]. More frequently they are synthesized and packed in China and/or India, and held for sale in Europe and Russian Federation [26]. According to the online survey of British clubmen in 2009, $43 \%$ respondents said they used mephedrone at least once [27]. In USA the number of cases of mephedrone intoxication has increased from 2009 to 2011, and started decreasing in 2012 [28, 29]. The prevalence of synthetic cathinones in USA among the senior pupils in 2012 was $1.3 \%$ [30], in schools of Germany the indices are the same: $2 \%$ [10].

Synthetic cathinones are serotonin, dopamine and non-adrenalin reuptake inhibitors. Selectivity changes from one substance to another [31]. The substances can be divided into three groups [32]:

cocaine-like type - MDMA of mixed type (mephedrone, methylone, ethylone, butylone, and naphyrone): nonspecific inhibition of reuptake monoamines (dopamine) is approximately five times as high than that of serotonin. All substances except naphyrone, promote serotonin release. Mephedrone contributes to dopamine release;

methamphetamine-like type (cathinone, flephedrone, and methcathinone): these substances selectively inhibit dopamine and norepinephrine reuptake and stimulate dopamine release;

pyrovalerone-like type (pyrovalerone, MDPV): selectively inhibit catecholamine reuptake, do not promote the release of monoamines.

Flephedrone, mephedrone and methcathinone are $5 \mathrm{HT}_{2 \mathrm{~A}}$-receptor agonists. Blood-brain barrier is highlypermeable for mephedrone and MDPV [31]. These

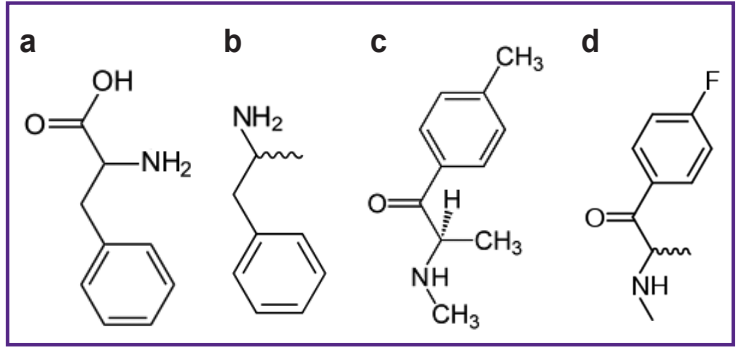

Figure 1. Synthetic cathinones: derivatives of bkamphetamine ( $\beta$-keto- $\alpha$-methyl-phenylalkilamin): (a) phenylalanyl; (b) amphetamine; (c) mephedrone; (d) flephedrone

substances are metabolized under isoenzymes of P-450 cytochrome and produced by the kidneys or biliary system [6].

Synthetic cathinones are usually taken in two ways: intranasally - by insufflating the powder through nose and by swallowing $[9,33]$. "Bombing" is the way of swallowing, when powder is wrapped in tissue paper and swallowed [34]. Conveniently, $1 \mathrm{~g}$ of the substance can be divided into 5-8 doses [35]. It has been known from the interviews of drug addicts undergoing treatment that the range of doses is wide, they varying from several $\mathrm{mg}$ to over $1 \mathrm{~g}[9,14,33,36]$. Consumers cannot know an accurate concentration of an active substance contained in powder, it depending on a manufacturer [33, 35].

Currently, the following descriptions are available: rectal administration, gum rubbing, inhalation, and intramuscular or intravenous administration [34, 27]. Mephedrone users say that a psychotropic effect comes 10-20 min after intranasal administration, with expected duration of about 1-2 h, after swallowing in 15-45 min with duration of 2-4 h. Those who prefer intravenous administration, report about a desired effect reaching its maximum within 10-15 min and with 30-minute duration [27].

The effects reported by users. Desired effects according to users of synthetic cathinones include: energy increase, sympathy and sociability, increased libido [14, 37]. Approximately $20 \%$ users stated the side effects of mephedrone [15, 33]: diaphoresis, palpitation, nausea and vomiting, headache, muscular twitching, vertigo and short memory loss (Table 1).

When comparing cocaine and mephedrone effects, $60-75 \%$ responds mentioned the longer effect of mephedrone; $50 \%$ considered mephedrone to have "the best" effect, while other $50 \%$ gave their preference to cocaine. The half of respondents stated the use of cocaine to be as dangerous as that of mephedrone. However, $25 \%$ respondents said mephedrone to be less dangerous, and $25 \%$ declared its complete safety $[27,39]$.

Several groups of substances are popular among the consumers of synthetic cathinones. More that 
Table 1

Clinical effects related to the use of synthetic cathinones, according to the users' reports $[14,27,35,37,38]$

\begin{tabular}{ll}
\hline $\begin{array}{l}\text { Manifestations in impaired functioning } \\
\text { of systems and target organs }\end{array}$ & Sylpitation, breathlessness, chest pain \\
\hline Cardiovascular system & Xerostomia, nasal bleeding, rhinalgia, nasal "burn", pain in oropharynx, tinnitus \\
\hline ENT & Stomachache, anorexia, nausea, vomiting \\
\hline Gastrointestinal tract & Anorgasmia, erectile dysfunction, increased libido \\
\hline Genitourinary system & Arthralgia, numbness, tingling, muscular rigidity and muscle spasm \\
\hline Musculoskeletal manifestations & Aggressiveness, teeth grinding, vertigo, headache, memory loss \\
\hline Neurological system & Visual deterioration, pupillary dilation (mydriasis) \\
\hline Ophthalmological manifestations & Shallow breathing \\
\hline Pulmonary manifestations & Anger, anxiety, auditory and visual hallucinations, depression, dysphoria, sympathy, euphoria, weariness, \\
\hline Psychological manifestations & formication (tactile hallucinations), short-period bursts of energy, enhanced and reduced attention \\
\hline Others & concentration, talkativeness, panic, paranoia, restlessness \\
\hline
\end{tabular}

$80 \%$ respondents reported about combined usage of cathinones with alcohol, smoking, MDMA, cannabis, cocaine [14]. All patients admitted to the intensive care unit with the diagnosis of mephedrone overdose used several drugs [36]. Screening assay of drug urinalysis [18] revealed 16 cases of 17 to show drugs of other groups. Frequently, the postmortem toxicological evaluation also shows the presence of drugs of different groups [40-42].

Those who use synthetic cathinones report about euphoria, increased motor activity, talkativeness, the origination of movement need, and the need to do something, mood improvement, reduced aggression, clear consciousness, sexual activity increase and increased music appreciation [27, 43]. The doses within the range of 5-20 mg are usually taken by mouth or intranasally, though rectal and intravenous administration is also possible [43].

The drugs of this group cause strong addiction with a constant desire to increase a dose: $80 \%$ users said that they purchased more mephedrone than they had initially intended [44]. There is the information about drug users who injected more than 10 single doses one by one [45]. Users concern most of all about their body odor, the smell appearing when using mephedrone [46]. The rare complications include: syncope, ST segment alterations, and myocarditis [47]. Psychotic changes after using "bath salts" include the following: paranoia with auditory and visual hallucinations [48], which can persist up to 4 weeks $[48,49]$. In most cases, intoxications proceeding with psychotic signs is the consequence of MDPV usage [29].

Side effects of using synthetic cathinones according to the records of specialized medical facilities. Cardiovascular, psychiatric and neurological symptoms and signs are the most common side effects of synthetic cathinones.

The most typical syndrome is excitement, which develops from moderate to severe psychosis requiring medical sedation. The retrospective data of British National Poisons Information Service shows that $28 \%$ cases of supposed intoxication caused by synthetic cathinones were accompanied by excitement and aggression [9]. In a clinical series of 72 patients admitted to London intensive care unit with suspected synthetic cathinone intoxication, $39 \%$ patients were in a state of excitement. Laboratory findings confirmed mephedrone use in nine of these patients [37]. In a retrospective review of Scottish intensive care unit data, excitement was also qualified as the most common sign [50]. The researches carried out in USA give evidence of excitement in $66 \%$ intoxication cases caused by synthetic cathinones [18].

The complications associated with cardiovascular system rank second after excitement and, according to various sources, account for $25-30 \%$. The difficulties in receiving reliable information are due to the fact that a substance causing intoxication is not always detected, or intoxication is caused by a combination intake of several substances [40-42].

Table 2 demonstrates the most common symptoms and syndromes accompanying synthetic cathinones inone intoxication mentioned in the reports of specialized medical centers. Hyponatremia is a common complication resulting from MDMA intake. Hyponatremia is considered to be the consequence of overhydratation caused by drug-induced secretion of vasopressin [51].

The role of synthetic cathinones in the changed balance between sodium and water in body is still unclear. In literature there are the descriptions of three cases of hyponatremia resulted from the intoxication of synthetic cathinones. Mephedrone was revealed in all three cases, while MDMA was not found.

A 14-year-old girl after taking alcohol with white color powder was admitted in critical condition, Glasgow coma scale score being 11 . The tests showed hyponatremia: 
Table 2

Clinical effects related to the use of synthetic cathinones, according to medical centers (including intensive care units) and poison control centers [9, 18, 37, 50, 52-55]

\begin{tabular}{ll}
\hline $\begin{array}{l}\text { Manifestations in impaired functioning } \\
\text { of systems and target organs }\end{array}$ & Chest pain, arterial hypertension, tachycardia, myocarditis \\
\hline Cardiovascular system & Nasal bleeding \\
\hline ENT & Stomachache, renal dysfunction, nausea, vomiting, renal failure \\
\hline Gastrointestinal tract & High creatinine kinase, peripheral vasoconstriction, rhabdomyolysis \\
\hline Musculoskeletal manifestations & $\begin{array}{l}\text { Excitement, aggression, mental status change, vertigo, drowsiness, } \\
\text { dystonia, headache, hyperreflexia, myoclonia, paraesthesiae }\end{array}$ \\
\hline Neurological system & Visual deterioration, mydriasis \\
\hline Ophthalmological manifestations & Shallow breathing, tachypnoea \\
\hline Pulmonary manifestations & Agitation, hallucinations, paranoia, psychosis \\
\hline Psychological manifestations & Renal dysfunction, acute renal failure \\
\hline Renal manifestations & Diaphoresis, fever, hyponatremia, skin rash \\
\hline Others &
\end{tabular}

$118 \mathrm{mmol} / \mathrm{L}$, with concurrent increased intracranial pressure. NMR revealed subcortex changes of the white matter. Neurological signs were arrested against the background sodium balance normalization. Moderate dysphasia and anterograde amnesia were persisting. Complete normalization was recorded two months later [56].

Two other cases were fatal. A 29-year-old man was admitted to the intensive care unit being in coma. Tests showed hyponatremia: $125 \mathrm{mmol} / \mathrm{L}$. Computed tomography revealed cerebral edema. He died after brain death after removing from life support [52].

An 18-year-old woman after taking cannabis and mephedrone underwent cardiac arrest. She was resuscitated. Tests revealed hyponatremia: $120 \mathrm{mmol} / \mathrm{L}$. Computed tomography revealed cerebral edema. She died $36 \mathrm{~h}$ after admission [57].

\section{Postmortem reports}

Mephedrone. The first fatal case of mephedrone intoxication accompanied by hyponatremia was described in Sweden [57]. Then reports of other fatal cases related to mephedrone intoxication followed. All those cases were studied and analyses were performed to reveal the role of mephedrone in the death cause. There were described four lethal cases associated with mephedrone usage that showed one of them to be reliably caused by mephedrone.

A 19-year-old man had convulsions several hours after taking mephedrone, MDMA and alcohol. When found, "his eye were rolling, and he was choking with cough". While being taken to hospital, he had heart arrest, and resuscitation had no effect, the patient passed away. The postmortem toxicological analysis showed alcohol, 3-fluoromethylphenylpiperazine and mephedrone in blood [41].

The second case was a 49-year-old woman, who felt acute retrosternal pain after mephedrone inhalation, alcohol drinking and cannabis smoking. The cause of death was mephedrone intoxication with accompanying factors, such as cardiac fibrosis and coronary artery atherosclerosis [41].

Moreover, mephedrone as a contributing factor was mentioned in two other cases: the death of a patient with multidrug overdosage, and a fatal crush [41].

Mephedrone caused the death of a man with delirium, who broke a pane of glass and cut his hands. The death was caused by mephedrone intoxication with excessive bleeding, however, the toxicological test revealed several substances except mephedrone: cocaine and its metabolites, MDMA [42].

In United Kingdom, from September 2009 to October 2011, there were recorded 128 fatal cases associated with mephedrone usage: of 62 cases that could be estimated, 26 deaths were caused by an acute toxic effect, and 18 suicides were committed against the background of a long-term intake of mephedrone [58]. MDPV, butylone and mephedrone played a key role in fatal cases in 2011 and 2012 [32].

Methedrone. Two fatal cases associated with methedrone use were recorded in Sweden. One of them had hyperthermia up to $42^{\circ} \mathrm{C}$. The autopsy in both cases revealed pulmonary tissue edema [59].

Butylone. There are reports about two deaths related to butylone intoxication. The first sufferer succumbed to injuries falling from height. The postmortem toxicological evaluation revealed butylone in blood. Another case: a woman died of taking butylone in combination with other substances. The autopsy discovered cerebral edema, pulmonary edema and multiple hemorrhages: in the lungs, liver, spleen and kidneys, as well as myocardial necrosis being found [60].

Currently, medical literature has no descriptions of fatal cases resulted from the intoxication of MDPV and other representatives of synthetic cathinones. 


\section{Synthetic cannabinoids}

The first experience on preparing substances having an effect on cannabinoid receptors can be referred to 1960s [61, 62]. First cyclohexylphenols (CP series) were first synthesized in the 70-80s by a pharmaceutical company Pfizer (USA) [63, 64]. Later, since the start of the 90s till the present time, a large part of cannabinoids has been synthesized under the guidance of American chemists John W. Huffman and A. Makriyannis, therefore these substances got the corresponding abbreviations: JWH and AM [65]. Synthesis of new substances (agonists, antagonists and inverse agonists) pursued several aims:

1) antagonists of the first subtype (CB1) cannabinoid receptors were considered as potential means for substance abuse (nicotine, opiate, cocaine, alcohol, cannabis, etc.) therapy, as well as for obesity treatment [66-68];

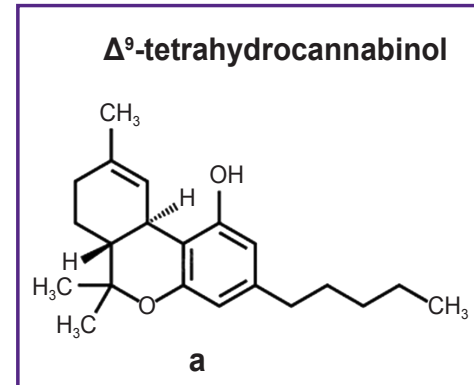

CP 47,497

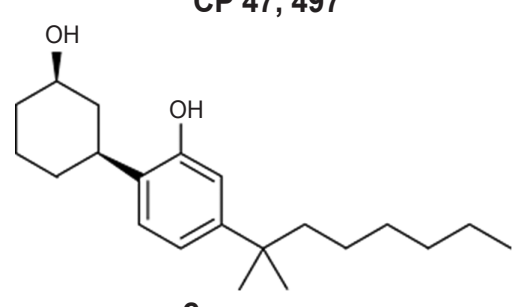

C

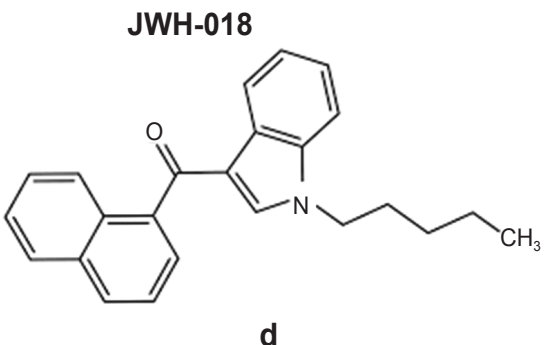

d
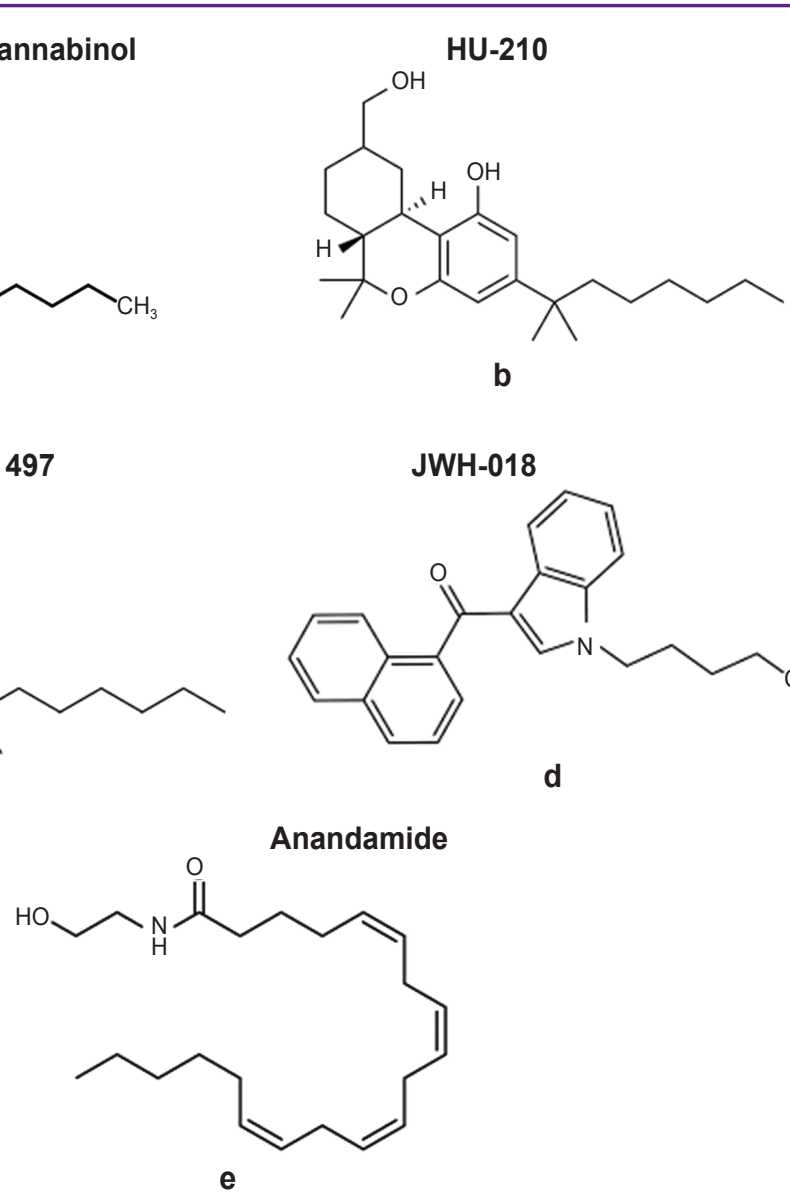

Figure 2. Classification of agonists of cannabinoid receptors according to their chemical structure [74]. Classical cannabinoids: (a) $\Delta^{9}$-tetrahydrocannabinol (THC), isolated from natural marihuana (Cannabis sativa); (b) nabilone, antiemetic agent, and HU (Hebrew University) cannabinoids, which have close affinity to THC; (c) nonclassical cannabinoids, such as cyclohexophenol; aminoalkylindoles: (d) JWH series, synthesized by a chemist J.W. Huffman; (e) eicosanoids, such as endocannabinoid anandamide
2) to obtain high-affinity ligands for cannabinoid CB2 receptors, since the agonists of corresponding receptors are presented by promising in the terms of the therapy of neurodegenerative, immune oncological and other diseases [69, 70];

3) to study endocannabinoid neurotransmitter systems $[65,71]$.

The first spice appeared in Europe in 2005. Its advertisement claimed that a psychotropic effect was due to its natural plant components [72]. Its true active Freiburg University (Germany), it appeared to be a synthetic agonist of cannabinoid receptors (CB) [73].

CB-agonists are classified according to their chemical structure [74] (Figure 2):

classical cannabinoids, such as $\Delta^{9}$-tetrahydrocannabinol (THC) isolated from natural marihuana (Cannabis sativa), antiemetic agent (nabilone) and $\mathrm{HU}$ (Hebrew University) cannabinoids, which have close affinity to THC;

nonclassical canabinoids, such as cyclohexophenol;

aminoalkylindoles - JWH series, synthesized by a chemist J.W. Huffman, contain many $\mathrm{CB}$ ligands;

eicosanoids, such as endocannabinoid anandamide.

Synthetic cannabinoids are sold under the mask of herb repertory, and presented as the substances of plant origin. However, the fact is that intact plant material is oversprayed by synthetic material, which comprises the most spice. The composition indicated on a pack with the herb frequently has nothing in common with the content. One gram of spice averages from 77.5 to $202 \mathrm{mg}$ of synthetic cannabinoid, the variability from one pack to another being high $[75,76]$. Thus, a consumer does not know what substance he uses and what the dose is. In addition, $\beta 2$-mimetic clenbuterol is often a part of the composition. It is responsible for sympathomimetic manifestations of spice intoxication, such as tachycardia, hypokalemia. Moreover, a large amount of tocopherol (vitamin E) can be found in the composition, and the function of tocopherol is the active substance masking [74].

The study of cannabinoid system showed several hundreds of agonists, which exhibit 
various affinity degrees to $\mathrm{CB} 1$ and $\mathrm{CB} 2$ receptors [4]. Endocannabinoid system participates in the regulation of physiological processes, such as thermal exchange, and controls the arterial smooth muscular tone [77, 78]. CB1 type receptors are located primarily in the nervous system, while CB2 receptors are in the spleen, tonsils, and immune cells, as well as on neurons of special kinds [74]. Synthetic cannabinoids are powerful agonists of CB1 receptors, and JWH-018 affinity to CB1 receptors is 5 times higher than in THC, and in AM-695 it is 500 times higher $[78,79]$.

The users say that spice has more psychotropic effect than marihuana [80]. Synthetic cannabinoids produce THC-like effect, with the change of mood, perception, sleep and wake, body temperature and cardiovascular system functioning [11]. Their side effects are more various and marked than those in THC. The most common ones are tachycardia, arterial hypertension, hyperglycemia, hypokalemia, hallucinations and excitement (Table 3).

Chest pain, myocardial ischemia and psychosis are rare in occurrence $[13,83]$. Since spice can contain different substances at different time, therefore, sideeffects will be different as well. In USA, for instance, fluorinated synthetic cannabinoid XLR-11 has obtained a wide circulation, its usage being related to the cases of acute renal failure in young men at the end of 2012 [72].

Synthetic cannabinoids are able to cause addiction $[13,83]$. Currently, there is little substantiated data on fatal cases resulted from the use of synthetic cannabinoids: one case of fatal coronal ischemia is known, as well as one suicide due to the depression following systematic substance usage [4].

\section{Other new psychoactive substances}

Piperazine derivatives. Piperazine is a medicinal agent, which is structurally related to various classes of preparations including antidepressants (e.g., trazodone), atypical antipsychotics (e.g., olanzapine), and antihistamines (e.g., cetirizine). Psychotropic derivatives of piperazine, such as 1-benzyl piperazine (BZP) and trifluoromethylphenylpiperazine (TFMPP), became narcotic drugs as early as in 2000 [84]. More frequently, they are oral, or taken in combination with other substances. Piperazine derivatives stimulate the release of dopamine, noradrenaline and serotonin, and inhibit reuptake [85].

Psychotropic substances BZP and TFMPP were studied in controlled researches. Intoxication manifestations are typical for stimulants. The study of effects in combination of alcohol was ceased due to high arterial hypertension, tachycardia, psychomotor agitation, restlessness, hallucinations, vomiting, insomnia and migraine [86]. The manifestations depend on substance concentration in plasma: $0-0.5 \mathrm{mg} / \mathrm{L}$ concentration is accompanied by panic, vomiting
Ta ble 3

Adverse effects of synthetic cathinones (intoxication after effects and signs)

$[11,74,81,82]$

\begin{tabular}{|c|c|}
\hline Functional impairments & Number (\%) \\
\hline \multicolumn{2}{|l|}{ Cardiovascular: } \\
\hline tachycardia & $37-76$ \\
\hline arterial hypertension & $10-34$ \\
\hline cardiogram alterations & $2-14$ \\
\hline chest pain & $7-10$ \\
\hline hypotonia & $2-7$ \\
\hline syncope & $3-4$ \\
\hline bradycardia & $2-3$ \\
\hline cardiac ischemia & $\mathrm{Nd}$ \\
\hline \multicolumn{2}{|l|}{ Neurological: } \\
\hline vertigo & $9-24$ \\
\hline loss of consciousness & $2-17$ \\
\hline drowsiness & $17-19$ \\
\hline sense shock & $2-10$ \\
\hline seizures & $3-4$ \\
\hline headaches & 3 \\
\hline ataxia & 2 \\
\hline shivering & 4 \\
\hline irritation & $\mathrm{Nd}$ \\
\hline \multicolumn{2}{|l|}{ Psychiatric: } \\
\hline excitement & $19-41$ \\
\hline hallucinations & $11-38$ \\
\hline anxiety/agitation & 21 \\
\hline confusion & $9-14$ \\
\hline anterograde amnesia & 7 \\
\hline psychosis & 3 \\
\hline aggressive behavior & 3 \\
\hline delusion & $\mathrm{Nd}$ \\
\hline \multicolumn{2}{|l|}{ Metabolic: } \\
\hline hyperglycemia & 31 \\
\hline hypokalemia & 28 \\
\hline other electrolytic changes & 2 \\
\hline \multicolumn{2}{|l|}{ Gastrointestinal: } \\
\hline nausea/vomiting & $9-28$ \\
\hline \multicolumn{2}{|l|}{ Renal: } \\
\hline renal failure & $\mathrm{Nd}$ \\
\hline \multicolumn{2}{|l|}{ Pulmonary: } \\
\hline breathlessness & 5 \\
\hline hyperventilation & $2-4$ \\
\hline \multicolumn{2}{|l|}{ Muscular: } \\
\hline increased creatine kinase & 14 \\
\hline myalgia & 7 \\
\hline \multicolumn{2}{|l|}{ Dermal: } \\
\hline xerostomia & 14 \\
\hline diaphoresis & 4 \\
\hline pallor & 1 \\
\hline photosensitivity & $\mathrm{Nd}$ \\
\hline \multicolumn{2}{|l|}{ Ophthalmological: } \\
\hline mydriasis & $3-38$ \\
\hline conjunctival hyperemia & 14 \\
\hline \multicolumn{2}{|l|}{ Others: } \\
\hline fever & 2 \\
\hline hyperthermia & $\mathrm{Nd}$ \\
\hline
\end{tabular}

He re: Nd - no data. 
and palpitation, the concentration over $0.5 \mathrm{mg} / \mathrm{L}$ is accompanied by excitement and confusion. Attacks can be caused lower concentrations as well: $0.05 \mathrm{mg} / \mathrm{L}$, and if the values are over $2.15 \mathrm{mg} / \mathrm{L}$ attacks occur regularly [87].

Aminoindans. Psychoactive substances of this group - MDAl (5,6-methylenedioxy-2-aminoindan), 5-IAI (5-iodo-2-aminoindan) and MMAI (5-methoxy6-methyl-2-aminoindan) - have the so called entactogenic effect (i.e. they enhance the perception of self-emotions), and therefore, they are sold as "legal" MDMA substitutes [88]. These preparations are weak inhibitors of monoamine reuptake, and except this they stimulate nonvesicular serotonin release. 5-IAI and MDAI have spread more widely after mephedrone was banned. Their expected effects are moderate euphoria, distortion of space and time perception, intensive color perception, and the thought that an addict understands better the emotions of other people. An effect starts 10 min after intake, and lasts for an hour, and then gradually becomes exhausted.

Side effects include cardiovascular and nervous disorders. Scientific literature offers not enough data on potential toxicity of 2-amonoindan derivatives. In the experimental study [88] the dose 40 times as high than the dose causing behavioral changes had no toxic effects (including neurotoxic). And still, it does not mean that the substances are safe: the users were found to have hyperemia, serotonin syndrome, acute necrosis of skeletal muscles, and there were fatal cases [88-90].

Brome Dragonfly. This substance, 1-(8-bromobenzo[1,2-b;4,5-b']difuran-4-yl)-2aminopropane, is a substituted phenylethylamine with a hallucination effect, similar to LSD [91]. It is a power agonist of 5-HT1, 5-HT2A and $\alpha_{1}$ receptors. The effect starts $6 \mathrm{~h}$ after intake in the form of visual and auditory hallucinations, a sense of well-being and solidarity, and can last for three days [91].

Due to the fact that the number of active substance varies from one lot to another, it may be a problem of overdosage [92]. Brome Dragonfly is very toxic, and can cause acidosis, pulmonary edema, a long-lasting angiospasm leading to gangrene and multiple organ failure $[91,93]$. There are reports about fatal cases. The case is known to have vascular spasm, which occurred after taking Brome Dragonfly; despite the therapy, the necrosis of toes developed [91, 93].

\section{Conclusion}

Today anyone taking NPS can choose a type of a desired narcotic effect, and the necessary narcotic is ordered at single-click ease. Many of these substances have already been included in Narcotic Drugs List and are illegal both in Europe and Russia. However, those who sell narcotic drugs, manage to find new ways to avoid the law and deliver their lethal products to consumers. The most unprotected group is young people, who think the use of NPS is safe and legal. This is precisely why this problem requires a new systemized approach, and adopting new prohibiting or limiting laws.

Federal Law dated February 3, 2015 No.7 "Concerning the Introduction of Amendments to Certain Legislative Acts of the Russian Federation" entered into force in the Russian Federation [94]. This law prescribes to make amendments in Federal Law dated January 8, 1998 No.3 "Concerning Narcotics and Psychotropic Substances" [95], we would like to mention the most significant of the amendments in the present review.

Article 1 of No.3 Law was amended by the paragraphs specifying:

"New potentially dangerous psychoactive substances - substances of synthetic or natural origin, included in the Register of new potentially hazardous psychoactive substances, which are illegal in the Russian Federation;

the trafficking of new potentially hazardous psychoactive substances - production, manufacturing, processing, storage, transporting, transmission, purchase, usage, importation into the Russian Federation, exportation from the Russian Federation, as well as the marketing of new potentially hazardous psychoactive substances (their sale, donation, exchange or their alienation to other people by any ways)".

Article 6.9 is amended by article 2, which introduces such concept as Register:

"The Register of potentially hazardous psychoactive substances, the trafficking of which is prohibited in the Russian Federation includes the substances causing in human the state of drug intoxication or other toxic intoxication dangerous to his life and health, as well as those, which have neither Sanitary and Epidemiological Requirements nor the measures of control over their trafficking specified by the appropriate authorities of the Russian Federation".

Moreover, article 2 presents the procedure to have the substances entered the Register. In turn, Register and Federal decisions on the control over the trafficking of narcotic drugs and psychotropic substances should be published in Internet.

On the other hand, there are still a number of problems requiring further explanations, namely: the determination of new psychoactive substances as the target of crime, their signs and a procedure of assigning them to the substances under control. Moreover, based on the law, there should be developed the methodological guidelines for assigning NPS to Register and then to the list.

Collaterally, from our point of view, it is necessary to carry out a strong information campaign to promote a healthy lifestyle among young people starting with children of primary school age. If we preserve a young generation, we will preserve our future. 
Study Funding. This study was not supported by any financial sources.

Conflict of Interests. The authors have no conflict of interests related to this study.

\section{References}

1. Carroll F.I., Lewin A.H., Mascarella S.W., Seltzman H.H., Reddy P.A. Designer drugs: a medicinal chemistry perspective. Ann N Y Acad Sci 2011; 1248(1): 1838, https://doi.org/10.1111/j.1749-6632.2011.06199.x.

2. Nobis F. "Legal-High"-Produkte — wirklich illegal? Oder: wie ein Aufsatz sich verselbstständigt. NStZ 2012; 422.

3. Europäische Beobachtungsstelle für Drogen und Drogensucht. Europäischer Drogenbericht. Trends und Entwicklungen. Luxemburg: Amt für Veröffentlichungen der Europäischen Union, 2013. URL: http://www.emcdda.europa. eu/attachements.cfm/att_213154_DE_TDAT13001DEN1.pdf.

4. Fattore L., Fratta W. Beyond THC: the new generation of cannabinoid designer drugs. Front Behav Neurosci 2011; 5: 60, https://doi.org/10.3389/fnbeh.2011.00060.

5. Rosenbaum C.D., Carreiro S.P., Babu K.M. Here today, gone tomorrow... and back again? A review of herbal marijuana alternatives (K2, Spice), synthetic cathinones (bath salts), kratom, Salvia divinorum, methoxetamine, and piperazines. J Med Toxicol 2012; 8(1): 15-32, https://doi.org/10.1007/ s13181-011-0202-2.

6. Meyer M.R., Wilhelm J., Peters F.T., Maurer H.H. Betaketo amphetamines: studies on the metabolism of the designer drug mephedrone and toxicological detection of mephedrone, butylone, and methylone in urine using gas chromatographymass spectrometry. Anal Bioanal Chem 2010; 397(3): 12251233, https://doi.org/10.1007/s00216-010-3636-5.

7. Kneisel S., Auwärter V., Kempf J. Analysis of 30 synthetic cannabinoids in oral fluid using liquid chromatography-electrospray ionization tandem mass spectrometry. Drug Test Anal 2012; 5(8): 657-669, https://doi. org/10.1002/dta.1429.

8. Kaurov Y.V., Larchenko A.V., Artyomenko A.G., Gnelitsky G.I., Mudrova S.A., Pankov A.V. Smoking mixture: medical and social aspects. Zdorov'e i obrazovanie $v X X I$ veke 2014; 16(4): 162-164.

9. James D., Adams R.D., Spears R., Cooper G., Lupton D.J., Thompson J.P., Thomas S.H.; National Poisons Information Service. Clinical characteristics of mephedrone toxicity reported to the UK National Poisons Information Service. Emerg Med J 2010; 28(8): 686-689, https://doi. org/10.1136/emj.2010.096636.

10. Bernard C., Werse B., Schell-Mack C. MoSyD. JAHRESBERICHT 2012. Drogentrends in Frankfurt am Main. Centre for Drug Research; 2013. URL: https://www.unifrankfurt.de/51782964/MoSyD-Jahresbericht-2012.pdf.

11. Hermanns-Clausen M., Kneisel S., Szabo B., Auwärter V. Acute toxicity due to the confirmed consumption of synthetic cannabinoids: clinical and laboratory findings. Addiction 2012; 108(3): 534-544, https://doi.org/10.1111/ j.1360-0443.2012.04078.x.

12. Musshoff F., Madea B., Kernbach-Wighton G., Bicker W., Kneisel S., Hutter M., Auwärter V. Driving under the influence of synthetic cannabinoids ("Spice"): a case series. Int J Legal Med 2013; 128(1): 59-64, https://doi.org/10.1007/ s00414-013-0864-1.

13. Zimmermann U.S., Winkelmann P.R., Pilhatsch M.,
Nees J.A., Spanagel R., Schulz K. Withdrawal phenomena and dependence syndrome after the consumption of "spice gold". Dtsch Arztebl Int 2009; 106(27): 464-467.

14. Winstock A.R., Mitcheson L.R., Deluca P., Davey Z., Corazza O., Schifano F. Mephedrone, new kid for the chop? Addiction 2011; 106(1): 154-161, https://doi.org/10.1111/ j.1360-0443.2010.03130.x.

15. Dargan P.I., Albert S., Wood D.M. Mephedrone use and associated adverse effects in school and college/university students before the UK legislation change. QJM 2010; 103(11): 875-879, https://doi.org/10.1093/qjmed/hcq134.

16. Kriikku P., Wilhelm L., Schwarz O., Rintatalo J. New designer drug of abuse: 3,4-methylenedioxypyrovalerone (MDPV). Findings from apprehended drivers in Finland. Forensic Sci Int 2011; 210(1-3): 195-200, https://doi. org/10.1016/j.forsciint.2011.03.015.

17. Winstock A., Mitcheson L., Marsden J. Mephedrone: still available and twice the price. Lancet 2010; 376(9752): 1537, https://doi.org/10.1016/s0140-6736(10)62021-1.

18. Centers for Disease Control and Prevention (CDC). Emergency department visits after use of a drug sold as "bath salts". Michigan, November 13, 2010-March 31, 2011. MMWR Morb Mortal Wkly Rep 2011; 60(19): 624-627.

19. Glennon R.A., Yousif M., Naiman N., Kalix P. Methcathinone: a new and potent amphetamine-like agent. Pharmacol Biochem Behav 1987; 26(3): 547-551, https://doi. org/10.1016/0091-3057(87)90164-x.

20. Graziani M., Milella M.S., Nencini P. Khat chewing from the pharmacological point of view: an update. Subst Use Misuse 2008; 43(6): 762-783, https://doi. org/10.1080/10826080701738992.

21. Al-Motarreb A., Al-Habori M., Broadley K.J. Khat chewing, cardiovascular diseases and other internal medical problems: The current situation and directions for future research. J Ethnopharmacol 2010; 132(3): 540-548, https:// doi.org/10.1016/j.jep.2010.07.001.

22. Kelly J.P. Cathinone derivatives: a review of their chemistry, pharmacology and toxicology. Drug Test Anal 2011; 3(7-8): 439-453, https://doi.org/10.1002/dta.313.

23. Emerson T.S., Cisek J.E. Methcathinone: A Russian designer amphetamine infiltrates the rural midwest. Ann Emerg Med 1993; 22(12): 1897-1903, https://doi.org/10.1016/s01960644(05)80419-6.

24. Goldberg J., Gardos G., Cole J.O. A controlled evaluation of pyrovalerone in chronically fatigued volunteers. Int Pharmacopsychiatry 1973; 8(1): 60-69.

25. Karila L., Reynaud M. GHB and synthetic cathinones: clinical effects and potential consequences. Drug Testing and Analysis 2010; 3(9): 552-559, https://doi.org/10.1002/ dta. 210.

26. Baron M., Elie M., Elie L. An analysis of legal highs-do they contain what it says on the tin? Drug Test Anal 2011; 3(9): 576-581, https://doi.org/10.1002/dta.274.

27. King's College London. Institute of psychiatry. Psychonaut Web Mapping Research Group. Spice report. London, UK; 2009.

28. Wood K.E. Exposure to bath salts and synthetic tetrahydrocannabinol from 2009 to 2012 in the United States. $J$ Pediatr 2013; 163(1): 213-216, https://doi.org/10.1016/j. jpeds.2012.12.056.

29. Spiller H.A., Ryan M.L., Weston R.G., Jansen J. Clinical experience with and analytical confirmation of "bath salts" and "legal highs" (synthetic cathinones) in the United States. 
Clinical Toxicology 2011; 49(6): 499-505, https://doi.org/10.310 9/15563650.2011.590812.

30. Maxwell J.C. Psychoactive substances - some new, some old: a scan of the situation in the U.S. Drug Alcohol Depend 2014; 134: 71-77, https://doi.org/10.1016/j. drugalcdep.2013.09.011.

31. Simmler L.D., Buser T.A., Donzelli M., Schramm Y., Dieu L.H., Huwyler J., Chaboz S., Hoener M.C., Liechti M.E. Pharmacological characterization of designer cathinones in vitro. Br J Pharmacol 2012; 168(2): 458-470, https://doi. org/10.1111/j.1476-5381.2012.02145.x.

32. Zawilska J.B., Wojcieszak J. Designer cathinones an emerging class of novel recreational drugs. Forensic Sci Int 2013; 231(1-3): 42-53, https://doi.org/10.1016/j. forsciint.2013.04.015.

33. Carhart-Harris R.L., King L.A., Nutt D.J. A web-based survey on mephedrone. Drug Alcohol Depend 2011; 118(1): 19-22, https://doi.org/10.1016/j.drugalcdep.2011.02.011.

34. Newcombe R. Mephedrone: the use of mephedrone (M-cat, meow) in Middlesbrough. Manchester, UK: Lifeline Publications; 2009.

35. Advisory Council on the Misuse of Drugs. Consideration of the cathinones. 2010. URL: http://www.namsdl.org/library/ E2E84A68-1372-636C-DD0E8D3A508B5F48/.

36. Wood D.M., Davies S., Puchnarewicz M., Button J., Archer R., Ovaska H., Ramsey J., Lee T., Holt D.W., Dargan P.I. Recreational use of mephedrone (4-methylmethcathinone, 4-MMC) with associated sympathomimetic toxicity. J Med Toxicol 2010; 6(3): 327-330, https://doi.org/10.1007/s13181010-0018-5.

37. Dargan P., Wood D. Technical report on mephedrone. In: EMCDDA. Risk assessments. Report on the risk assessment of mephedrone in the framework of the Council Decision on new psychoactive substances. Lisbon; 2011; p. 49-102.

38. Schifano F., Albanese A., Fergus S., Stair J.L., Deluca P., Corazza O., Davey Z., Corkery J., Siemann H., Scherbaum N., Farre' M., Torrens M., Demetrovics Z., Ghodse A.H.; Psychonaut Web Mapping; ReDNet Research Groups. Mephedrone (4-methylmethcathinone; "meow meow"): chemical, pharmacological and clinical issues. Psychopharmacology 2010; 214(3): 593-602, https://doi. org/10.1007/s00213-010-2070-x.

39. Brunt T.M., Poortman A., Niesink R.J., van den Brink W. Instability of the ecstasy market and a new kid on the block: mephedrone. J Psychopharmacol 2011; 25(11): 1543-1547, https://doi.org/10.1177/0269881110378370.

40. Dickson A.J., Vorce S.P., Levine B., Past M.R. Multiple-drug toxicity caused by the coadministration of 4-methylmethcathinone (mephedrone) and heroin. J Anal Toxicol 2010; 34(3): 162-168, https://doi.org/10.1093/ jat/34.3.162.

41. Maskell P.D., De Paoli G., Seneviratne C., Pounder D.J. Mephedrone (4-methylmethcathinone)-related deaths. J Anal Toxicol 2011; 35(3): 188-191, https://doi. org/10.1093/anatox/35.3.188.

42. Torrance H., Cooper G. The detection of mephedrone (4-methylmethcathinone) in 4 fatalities in Scotland. Forensic Sci Int 2010; 202(1-3): e62-e63, https://doi.org/10.1016/j. forsciint.2010.07.014.

43. Ross E.A., Watson M., Goldberger B. "Bath Salts" intoxication. N Engl J Med 2011; 365(10): 967-968, https://doi. org/10.1056/nejmc1107097.

44. Freeman T.P., Morgan C.J.A., Vaughn-Jones J.,
Hussain N., Karimi K., Curran H.V. Cognitive and subjective effects of mephedrone and factors influencing use of a "new legal high". Addiction 2012; 107(4): 792-800, https://doi. org/10.1111/j.1360-0443.2011.03719.x.

45. Belton P., Sharngoe T., Maguire F.M., Polhemus M. Cardiac infection and sepsis in 3 intravenous bath salts drug users. Clin Infect Dis 2013; 56(11): e102-e104, https://doi. org/10.1093/cid/cit095.

46. Penders T.M., Gestring R.E., Vilensky D.A. Excited delirium following use of synthetic cathinones (bath salts). Gen Hosp Psychiatry 2012; 34(6): 647-650, https://doi. org/10.1016/j.genhosppsych.2012.06.005.

47. Nicholson P.J., Quinn M.J., Dodd J.D. Headshop heartache: acute mephedrone 'meow' myocarditis. Heart 2010; 96(24): 2051-2052, https://doi.org/10.1136/hrt.2010.209338.

48. Loeffler G., Penn A., Ledden B. "Bath salt"-induced agitated paranoia: a case series. J Stud Alcohol Drugs 2012; 73(4): 706-706, https://doi.org/10.15288/jsad.2012.73.706.

49. Borek H.A., Holstege C.P. Hyperthermia and multiorgan failure after abuse of "bath salts" containing 3,4-methylenedioxypyrovalerone. Ann Emerg Med 2012; 60(1): 103-105, https://doi.org/10.1016/j.annemergmed.2012. 01.005 .

50. Regan L., Mitchelson M., Macdonald C. Mephedrone toxicity in a Scottish emergency department. Emerg Med J 2010; 28(12): 1055-1058, https://doi.org/10.1136/emj.2010.103093.

51. Henry J.A., Fallon J.K., Kicman A.T., Hutt A.J., Cowan D.A., Forsling M. Low-dose MDMA ("ecstasy") induces vasopressin secretion. Lancet 1998; 351(9118): 1784, https:// doi.org/10.1016/s0140-6736(05)78744-4.

52. Wood D.M., Davies S., Greene S.L., Button J., Holt D.W., Ramsey J., Dargan P.I. Case series of individuals with analytically confirmed acute mephedrone toxicity. Clin Toxicol (Phila) 2010; 48(9): 924-927, https://doi.org/10.3109/1 5563650.2010 .531021 .

53. Fröhlich S., Lambe E., O'Dea J. Acute liver failure following recreational use of psychotropic "head shop" compounds. Ir J Med Sci 2010; 180(1): 263-264, https://doi. org/10.1007/s11845-010-0636-6.

54. Winstock A., Mitcheson L., Ramsey J., Davies S., Puchnarewicz M., Marsden J. Mephedrone: use, subjective effects and health risks. Addiction 2011; 106(11): 1991-1996, https://doi.org/10.1111/j.1360-0443.2011.03502.x.

55. Shimizu E., Watanabe H., Kojima T., Hagiwara H., Fujisaki M., Miyatake R., Hashimoto K., lyo M. Combined intoxication with methylone and 5-MeO-MIPT. Prog Neuropsychopharmacol Biol Psychiatry 2007; 31(1): 288-291, https://doi.org/10.1016/j.pnpbp.2006.06.012.

56. Sammler E.M., Foley P.L., Lauder G.D., Wilson S.J., Goudie A.R., O'Riordan J.I. A harmless high? Lancet 2010; 376(9742): 742, https://doi.org/10.1016/s0140-6736(10) 60891-4.

57. Gustavsson D., Escher C. Mephedrone - internet drug which seems to have come and stay. Fatal cases in Sweden have drawn attention to previously unknown substance. Lakartidningen 2009; 106(43): 2769-2771.

58. Schifano F., Corkery J., Ghodse A.H. Suspected and confirmed fatalities associated with mephedrone (4-methylmethcathinone, "meow meow") in the United Kingdom. J Clin Psychopharmacol 2012; 32(5): 710-714, https://doi.org/10.1097/jcp.0b013e318266c70c.

59. Wikstrom M., Thelander G., Nystrom I., Kronstrand R. Two fatal intoxications with the new designer drug methedrone 
(4-methoxymethcathinone). J Anal Toxicol 2010; 34(9): 594598, https://doi.org/10.1093/jat/34.9.594.

60. Carter N., Rutty G.N., Milroy C.M., Forrest A.R.W. Deaths associated with MBDB misuse. Int J Legal Med 2000; 113(3): 168-170, https://doi.org/10.1007/s004140050291.

61. Harbert C.A., Johnson M.R., Melvin L.S.Jr. 3-[Hydroxy4-(substituted)-phenyl]-cycloalkanone and cycloalkanol derivatives. DE Patent 2839836. 1979.

62. Weissman A., Milne G.M., Melvin L.S. Jr. Cannabimimetic activity from CP-47,497, a derivative of 3-phenylcyclohexanol. J Pharmacol Exp Ther 1982; 223(2): 516-523.

63. Little P.J., Compton D.R., Mechoulam R., Martin B.R. Stereochemical effects of 11-OH- $\Delta 8-\mathrm{THC}$-dimethylheptyl in mice and dogs. Pharmacol Biochem Behav 1989; 32(3): 661666, https://doi.org/10.1016/0091-3057(89)90014-2.

64. Mechoulam R., Feigenbaum J.J., Lander N., Segal M., Järbe T.U.C., Hiltunen A.J., Consroe P. Enantiomeric cannabinoids: stereospecificity of psychotropic activity. Experientia 1988; 44(9): 762-764, https://doi.org/10.1007/ bf01959156.

65. Howlett A.C., Barth F., Bonner T.I., Cabral G., Casellas P., Devane W.A., Felder C.C., Herkenham M., Mackie K., Martin B.R., Mechoulam R., Pertwee R.G. International Union of Pharmacology. XXVII. Classification of Cannabinoid Receptors. Pharmacol Rev 2002; 54(2): 161202, https://doi.org/10.1124/pr.54.2.161.

66. Crippa J.A., Zuardi A.W., Hallak J.E. Therapeutical use of the cannabinoids in psychiatry. Rev Bras Psiquiatr 2010; 32(Suppl 1): S56-66.

67. Escobar-Chávez J.J., Domínguez-Delgado C.L., Rodríguez-Cruz I.M. Targeting nicotine addiction: the possibility of a therapeutic vaccine. Drug Des Devel Ther 2011; 211, https://doi.org/10.2147/dddt.s10033.

68. Justinova Z., Panlilio L.V., Goldberg S.R. Drug addiction. Curr Top Behav Neurosci 2009; 309-346, https://doi. org/10.1007/978-3-540-88955-7_13.

69. Fernández-Ruiz J., Moreno-Martet M., RodríguezCueto C., Palomo-Garo C., Gómez-Cañas M., Valdeolivas S., Guaza C., Romero J., Guzmán M., Mechoulam R., Ramos J.A. Prospects for cannabinoid therapies in basal ganglia disorders. Br J Pharmacol 2011; 163(7): 1365-1378, https://doi. org/10.1111/j.1476-5381.2011.01365.x.

70. Sánchez A.J., García-Merino A. Neuroprotective agents: Cannabinoids. Clin Immunol 2012; 142(1): 57-67, https://doi.org/10.1016/j.clim.2011.02.010.

71. Howlett A.C., Breivogel C.S., Childers S.R., Deadwyler S.A., Hampson R.E., Porrino L.J. Cannabinoid physiology and pharmacology: 30 years of progress. Neuropharmacology 2004; 47: 345-358, https://doi.org/10. 1016/j.neuropharm.2004.07.030.

72. Centers for Disease Control and Prevention. Acute kidney injury associated with synthetic cannabinoid use multiple states 2012. MMWR Morb Mortal Wkly Rep 2013; 62: 93-98.

73. Auwärter V., Dresen S., Weinmann W., Müller M., Pütz M., Ferreirós N. "Spice" and other herbal blends: harmless incense or cannabinoid designer drugs? J Mass Spectrom 2009; 44(5): 832-837, https://doi.org/10.1002/jms.1558.

74. Seely K.A., Prather P.L., James L.P., Moran J.H. Marijuana-based drugs: innovative therapeutics or designer drugs of abuse? Mol Interv 2011; 11(1): 36-51.

75. Simolka K., Lindigkeit R., Schiebel H.-M., Papke U., Ernst L., Beuerle T. Analysis of synthetic cannabinoids in "spice-like" herbal highs: snapshot of the German market in summer 2011. Anal Bioanal Chem 2012; 404(1): 157-171, https://doi.org/10.1007/s00216-012-6122-4.

76. Hillebrand J., Olszewski D., Sedefov R. Legal highs on the internet. Subst Use Misuse 2010; 45(3): 330-340, https:// doi.org/10.3109/10826080903443628.

77. Randall M.D., Kendall D.A., O'Sullivan S. The complexities of the cardiovascular actions of cannabinoids. Br J Pharmacol 2004; 142(1): 20-26, https://doi.org/10.1038/ sj.bjp.0705725.

78. Atwood B.K., Huffman J., Straiker A., Mackie K. JWH018, a common constituent of "Spice" herbal blends, is a potent and efficacious cannabinoid CB 1 receptor agonist. $\mathrm{Br}$ J Pharmacol 2010; 160(3): 585-593, https://doi.org/10.1111/ j.1476-5381.2009.00582.x.

79. Psychoyos D., Vinod K.Y. Marijuana, Spice 'herbal high', and early neural development: implications for rescheduling and legalization. Drug Test Anal 2013; 5(1): 27-45, https://doi. org/10.1002/dta.1390.

80. Griffiths P., Sedefov R., Gallegos A., Lopez D. How globalization and market innovation challenge how we think about and respond to drug use: "Spice" a case study. Addiction 2010; 105(6): 951-953, https://doi.org/10.1111/j.13600443.2009.02874.x.

81. Forrester M.B. Synthetic cathinone exposures reported to Texas poison centers. Am J Drug Alcohol Abuse 2012; 38(6): $\quad 609-615$, https://doi.org/10.3109/00952990.2012. 677890.

82. Gunderson E.W., Haughey H.M., Ait-Daoud N., Joshi A.S., Hart C.L. "Spice" and "K2" herbal highs: a case series and systematic review of the clinical effects and biopsychosocial implications of synthetic cannabinoid use in humans. Am J Addict 2012; 21(4): 320-326, https://doi. org/10.1111/j.1521-0391.2012.00240.x.

83. Müller H., Sperling W., Köhrmann M., Huttner H.B., Kornhuber J., Maler J.-M. The synthetic cannabinoid Spice as a trigger for an acute exacerbation of cannabis induced recurrent psychotic episodes. Schizophr Res 2010; 118(1-3): 309-310, https://doi.org/10.1016/j.schres.2009.12.001.

84. De Boer D., Bosman I.J., Hidvégi E., Manzoni C., Benkö A.A., dos Reys L.J.A., Maes R.A. Piperazine-like compounds: a new group of designer drugs-of-abuse on the European market. Forensic Sci Int 2001; 121(1-2): 47-56, https://doi.org/10.1016/s0379-0738(01)00452-2.

85. Elliott S. Current awareness of piperazines: pharmacology and toxicology. Drug Test Anal 2011; 3(7-8): 430-438, https://doi.org/10.1002/dta.307.

86. Thompson I., Williams G., Caldwell B., Aldington S., Dickson S., Lucas N., McDowall J., Weatherall M., Robinson G., Beasley R. Randomised double-blind, placebo-controlled trial of the effects of the "party pills" BZP/TFMPP alone and in combination with alcohol. J Psychopharmacol 2010; 24(9): 1299-1308, https://doi.org/10.1177/0269881109102608.

87. Gee P., Gilbert M., Richardson S., Moore G., Paterson S., Graham P. Toxicity from the recreational use of 1-benzylpiperazine. Clin Toxicol (Phila) 2008; 46(9): 802-807, https://doi.org/10.1080/15563650802307602.

88. Coppola M., Mondola R. 5-lodo-2-aminoindan (5$|A|)$ : chemistry, pharmacology, and toxicology of a research chemical producing MDMA-like effects. Toxicol Lett 2013; 218(1): 24-29, https://doi.org/10.1016/j.toxlet.2013.01.008.

89. Sainsbury P.D., Kicman A.T., Archer R.P., King L.A., Braithwaite R.A. Aminoindanes-the next wave of "legal highs"? 
Drug Test Anal 2011; 3(7-8): 479-482, https://doi.org/10.1002/ dta.318.

90. Corkery J.M., Elliott S., Schifano F., Corazza O., Ghodse A.H. MDAl (5,6-methylenedioxy-2-aminoindane; 6,7-dihydro-5H-cyclopenta[f][1,3]benzodioxol-6-amine; "sparkle"; "mindy") toxicity: a brief overview and update. Hum Psychopharmacol 2013; 28(4): 345-355, https://doi. org/10.1002/hup.2298.

91. Corazza O., Schifano F., Farre M., Deluca P., Davey Z., Torrens M., Demetrovics Z., Di Furia L., Flesland L., Siemann H., Skutle A., Van Der Kreeft P., Scherbaum N. Designer drugs on the internet: a phenomenon out-of-control? The emergence of hallucinogenic drug bromo-dragonfly. Curr Clin Pharmacol 2011; 6(2): 125-129, https://doi. org/10.2174/157488411796151129.

92. King's College London. Institute of psychiatry.
Psychonaut Web Mapping Research Group. Bromo-dragonfly report. London, UK; 2009.

93. Thorlacius K., Borna C., Personne M. Bromo-dragon fly - life-threatening drug. Can cause tissue necrosis as demonstrated by the first described case. Lakartidningen 2008; 105916): 1199-1200.

94. Federal'nyy zakon Rossiyskoy Federatsii ot 3 fevralya 2015 g. №7-FZ "O vnesenii izmeneniy $v$ otdel'nye zakonodatel'nye akty Rossiyskoy Federatsii" [Federal Law of the Russian Federation dated February 3, 2015 No.7FL "Concerning the Introduction of Amendments to Certain Legislative Acts"].

95. Federal'nyy zakon ot 8 yanvarya 1998 goda №3-FZ "O narkoticheskikh sredstvakh i psikhicheskikh veshchestvakh" [Federal Law dated January 8, 1998 No.3-FL "Concerning Narcotics and Psychotropic Substances"]. 